\title{
DYNAMIC SIMULATION OF AN AIR-GAP MEMBRANE DISTILLATION (AGMD) PROCESS USING PHOTOVOLTAIC PANELS SYSTEM AND FLAT PLATE COLLECTORS
}

\author{
Abdelfatah Marni Sandid ${ }^{1, *}$, Driss Nehari ${ }^{1}$, Abderrahmane Elmeriah ${ }^{1}$, Ahmed Remlaoui ${ }^{1}$
}

\begin{abstract}
In the desalination field, the membrane distillation (MD) is a new process of producing distilled water that has been developed and tested in recent years. In this paper, the integrated single cassette air-gap membrane distillation (AGMD) module in the solar thermal desalination system is validated and numerically simulated with the TRNSYS program. This model is studied to be ideal for obtaining a distilled water flow rate of $5.5 \mathrm{~kg} / \mathrm{h}$ at different times under changing climatic conditions throughout the year in Ain-Temouchent weather, Algeria. The auxiliary heater is added to ensure the thermal energy continuity in the cold climatic conditions, where the photovoltaic system is used to power electrically the auxiliary heater. Therefore, the energy needed is calculated for the auxiliary heater and is replaced by 10 photovoltaic panels, each one has an area of $1.6 \mathrm{~m}^{2}$ using seven of the energy storage batteries $(12 \mathrm{~V}, 200 \mathrm{Ah})$ with $1.5 \mathrm{KW}$ via TRNSYS and PVGIS help programs. Simulated results showed excellent compatibility with experimental results in previous studies. Additionally, it was found that when the inlet temperature of AGMD reaches $85{ }^{\circ} \mathrm{C}$, the distilled water flow from the distillation membrane reaches $5.5 \mathrm{~kg} / \mathrm{h}$ and that remains stable on different days throughout the year by relying solely on solar energy.
\end{abstract}

Keywords: Membrane Distillation, Solar Water Heater, Flat Plate Collector, Photovoltaic System, Trnsys

\section{INTRODUCTION}

Several technologies are used to produce potable water in different places of the world, and membrane distillation (MD) is a new process of producing distilled water that had been used many years ago. MD process appears as an attractive solution with a free energy source (solar energy) [1-2]. MD is a thermally driven separation process in which only the vapor molecules pass through a microporous hydrophobic membrane. The driving force in the MD process is the vapor pressure difference induced by the temperature difference across the membrane surface. This process has various applications such as desalination, wastewater treatment and the food industry [3-4]. The advantages of MD desalination via working on low-grade temperature sources (less than $100{ }^{\circ} \mathrm{C}$ ), $100 \%$ salt rejection with low fouling and operating pressure [5] make it more efficient methods for desalination application. Until now, the most employed studies of MD hydrophobic micro-porous membranes commercially available have been based on polypropylene (PP), polyethylene (PE), polytetrafluoroethylene (PTFE), or polyvinylidene fluoride (PVDF) [6].

In light of the review of work done by Verma SK et al. [7], the efficiency of the membrane decreases due to its contamination by agglomeration of particles. Self-cleaning smart nanomaterials may be a suitable choice to solve the problem. Therefore, photocatalytic methods of purification can be modified by adopting hybrid nanomaterials photocatalytic, which can widen the absorption of ultraviolet-visible spectra for producing reactive oxygen radicals, which damage the cell wall of harmful bacteria and simultaneously absorb more heat energy at the higher temperature to raise the rate of the process.

Recently, various MD processing technics have appeared as solutions have a free energy source and diversity of membrane distillations technologies such as Direct Contact Membrane Distillation (DCMD), Vacuum Membrane Distillation (DMV), Air Gap Membrane Distillation (AGMD), and Sweeping Gas Membrane Distillation (SGMD)[8]. According to the high-energy costs associated with existing desalination methods, there is a great demand for technologies that can use low-temperature sources like waste heat or solar energy. DCMD is the most MD configuration technology studied due to the simplicity and ease of handling, where its energy efficiency, called the membrane thermal

This paper was recommended for publication in revised form by Regional Editor Tolga Taner

${ }^{1}$ Smart Structures Laboratory, University Center of Ain-Temouchent, 46000 Ain-Temouchent, Algeria

^E-mail address: abdelfatahsandid@hotmail.com / fatah.marnisandid@cuniv-aintemouchent.dz

Orcid id: 0000-0001-7592-9672, 0000-0002-9371-1105, 0000-0003-2475-4491, 0000-0001-6179-6493

Manuscript Received 25 February 2020, Accepted 17 May 2020 
efficiency (MTE), is commonly related to the operating conditions [9]. In the MD process field, the DCMD process has a lower MTE against the AGMD procedure because of conduction heat losses. The mechanism functions of the AGMD systems based on the stagnant air gap interposition between the membrane and condensation area, which leads to an inherently increasing of the thermal energy efficiency of the process [10]. Consequently, the first patent to discuss the principle of AGMD appeared with G. L. Hassler [11] and P. K. Weyl [12] for the basics knowledge, in which the concept and behavior of AGMD systems can be found in different literature studies [13, 14, 15]. Hanemaaijer et al. [16] introduced an idea of internal heat recovery that is called memstill membrane distillation. Sequentially, Duong et al. $[17,18]$ conducted a study that allowed only AGMD to restore the latent heat without any external heat exchanger. Minier-Matar et al. [19] found through their study that AGMD provides a higher resistance to mass transfer and runs at low water flow.

Schwantes et al. [20] gave the high thermal efficiency in AGMD; it was the first choice for experimental test stations dealing with long-term operation and expansion problems, where these AGMD modules can be made with cheap polymeric corrosion-resistant materials [21].

Although recent developments in AGMD configurations, the first flat plate AGMD system was developed by the Swedish Svenska Utvecklings AB in 2016 [22], while such modules today are manufactured and commercialized by Scarab Development. Each module is made up of 10 planar cassettes with an overall membrane surface of $2.3 \mathrm{~m} 2$ and a global capacity of 1-2 m3/d of distillate water [23]. The single-stage consists of injection-molded plastic frames containing two parallel membranes, feed and exit channels for warm water and two condensing walls [22,24]. Achmad Chafidz et al.. [25] developed a portable hybrid solar-powered membrane distillation system for the production of freshwater using Vacuum Multi-Effect Membrane Distillation. The total volume distillate output during the test was approximately $70 \mathrm{~L}$ with an approximate conductivity of $4.7 \mu \mathrm{S} / \mathrm{cm}$. The average distillate output rate was $11.53 \mathrm{~L} / \mathrm{h}$ with a maximum of $15.94 \mathrm{~L} / \mathrm{h}$ at noontime, whereas the distillate flux was in the range of $1.5-2.6 \mathrm{~L} / \mathrm{m} 2 \mathrm{~h}$.

Kullab et al. [26] studied the solar thermal integrated AGMD unit having non-concentrating solar thermal collectors. The trials were conducted on this test facility with different parametric analyses (feedstock, Total Dissolved Solid levels, temperature, and flow rates) and the data from the experiments and related studies demonstrated that the MD unit performance remains insensitive to variations in feedstock qualities (e.g. PH, TDS levels).

On the other hand, Banat and Simandl [27] used membranes of different porosities for desalinating water by using Air Gap Membrane Distillation (AGMD) technique. The results demonstrated that the permeate flux increased exponentially with the increase in hot side temperature. Khan et al. [28] conducted experimental analysis from arsenic removal using single cassette AGMD with an effective membrane area of $0.2 \mathrm{~m} 2$ and reported fluxes of $20 \mathrm{~L} / \mathrm{m}^{2} \mathrm{~h}$ at a temperature difference of $50^{\circ} \mathrm{C}$ between hot and cold inlet temperatures. He et al. [29] applied factorial design and RSM to analyze the relationships between operating parameters (hot and cold inlet temperatures, feed flow rate) on performance indicators including distillate flux and gained output index of a hollow fiber AGMD module.

In Kumar's work et al. [30], a single cassette air-gap membrane distillation (AGMD) module characterized to identify the effect of process parameters on distillate flux and thermal efficiency. Favorable conditions to obtain a distillate flow rate of 5-6 kg/h determined on a bench-scale experimental setup. The developed RSM regression model tested by analysis of variance (ANOVA) and validated using experimental results of Asim et al. [31]. Parametric optimization carried out as well to identify suitable conditions for operating MD with constant or dynamic energy supply (e.g. solar thermal energy). Then, experiments on a solar MD system were carried out in October during which maximum radiation would be incident on solar collectors installed in the United Arab Emirates (UAE).

In this paper, a numerical model of desalination that depends on single cassette air-gap membrane distillation (AGMD) module integrated solar thermal system is validated with simulation results of Kumar et al. [30] which was carried out experiments on solar MD system only in October on solar collectors installed in UAE as previously mentioned [31]. Therefore, this model is dynamically simulated with the TRNSYS (transient system simulation) program to be an ideal model of obtaining a distilled water flow rate of $5.5 \mathrm{~kg} / \mathrm{h}$ at different times at changing climatic conditions throughout the year in Ain-Temouchent weather. Then, the auxiliary heater adds to compensate the lost thermal energy in cold climatic conditions, and the photovoltaic system adds the energy storage battery that the heater needs. Thus, it saved costs by relying on solar energy only as renewable energy for this model used in desalination 
Journal of Thermal Engineering, Research Article, Vol. 7, No. 2, Special Issue 13, pp. 117-133, February, 2021

throughout the year using modern membrane distillation technology (AGMD). Therefore, this model is suitable to be a compatible system with all intermittent weather climatic conditions in Ain-Temouchent, Algeria.

\section{SYSTEM DESCRIPTION}

\section{Thermal system}

The studied system contains the thermal energy loop, as shown in figure 1 . The system incorporating a flat plate collector (FPC) with an area of $12.75 \mathrm{~m}^{2}$, heat exchanger internal, and auxiliary heaters providing heat via freshwater heat transfer fluid to MD hot water store containing $100 \mathrm{~L}$ with a pump and a controller in differential temperature as shown in Fig 1.

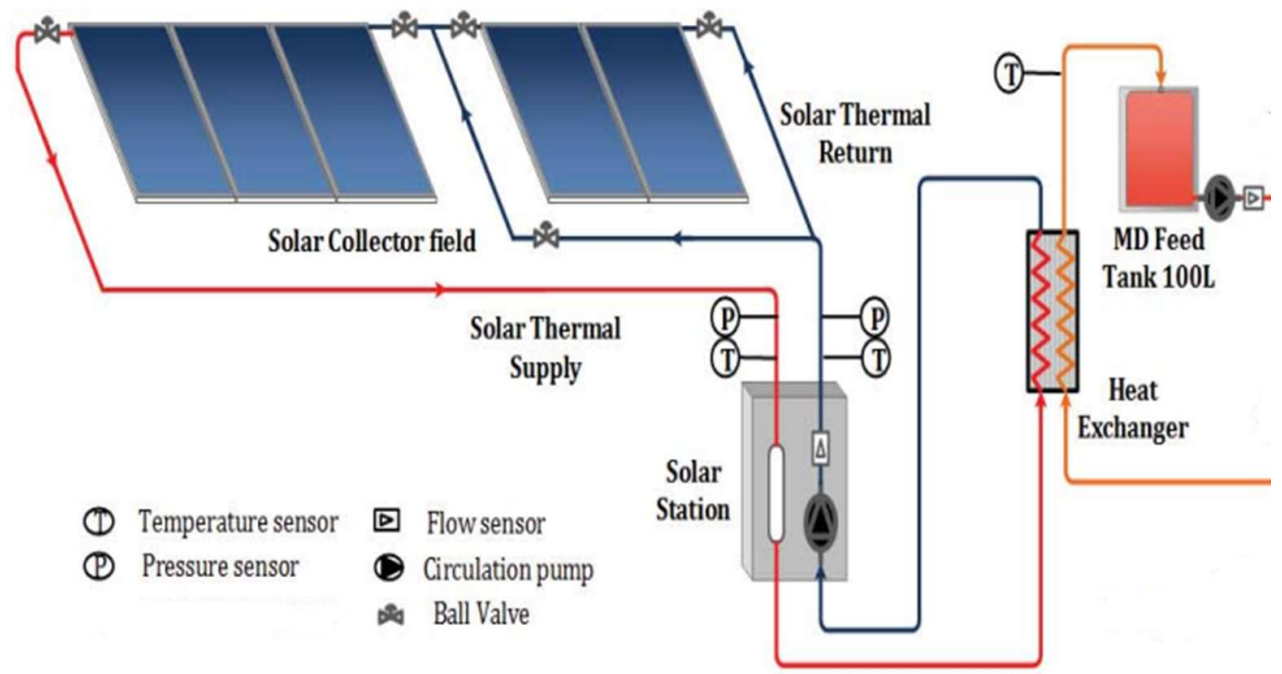

Figure 1. Schematic showing an operation of solar domestic hot water (SDHW).

\section{Photovoltaic system}

The solar PV system consists of different components that must be selected according to the type of system, the location of the site and the applications. The main components of the solar photovoltaic system are the solar charge controller, the inverter, the group of batteries, the auxiliary power sources and the loads (devices) as shown in Fig 2.

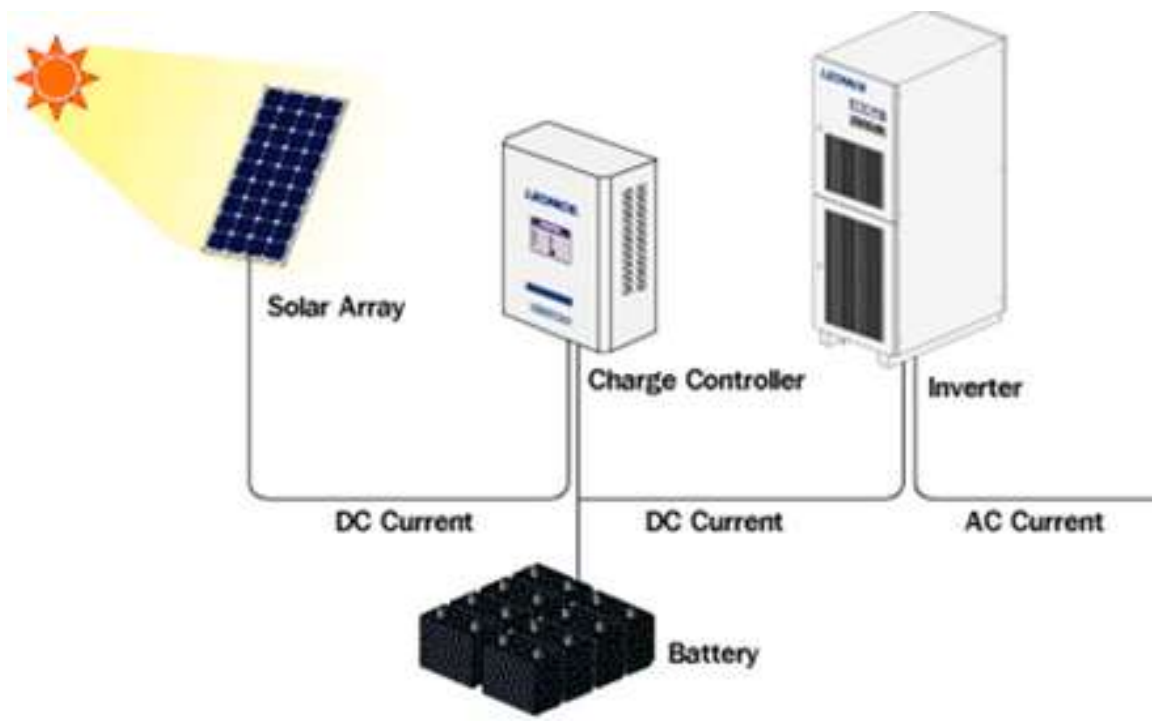

Figure 2. Synoptic representation of the structure of a photovoltaic system with storage 


\section{AGMD process}

AGMD is a configuration of membrane distillation (MD) in which an air layer is interposed between a porous hydrophobic membrane and the condensation surface. In the process, volatile compounds (including water) present in a warm feed evaporate at the liquid/vapor interface formed at the membrane surface. The vapor is transferred through the membrane pores and the air gap then finally condenses on a cold surface inside the membrane module. The driving force of the mass transfer in AGMD is the difference in vapor pressure on both sides of the membrane. The present work utilizes a bench-scale AGMD unit with a single membrane cassette developed in collaboration with an industrial research partner. Fig 3 shows the layout of components in the bench-scale MD module and shows the picture of the module fitted with the cassette in a plate and frame configuration. Specifications of the membrane cassette are:

Material: hydrophobic PTFE membrane.

Pore size: $0.2 \mu \mathrm{m}$; thickness: $280 \mu \mathrm{m}$; total membrane area: $0.2 \mathrm{~m}^{2}$.
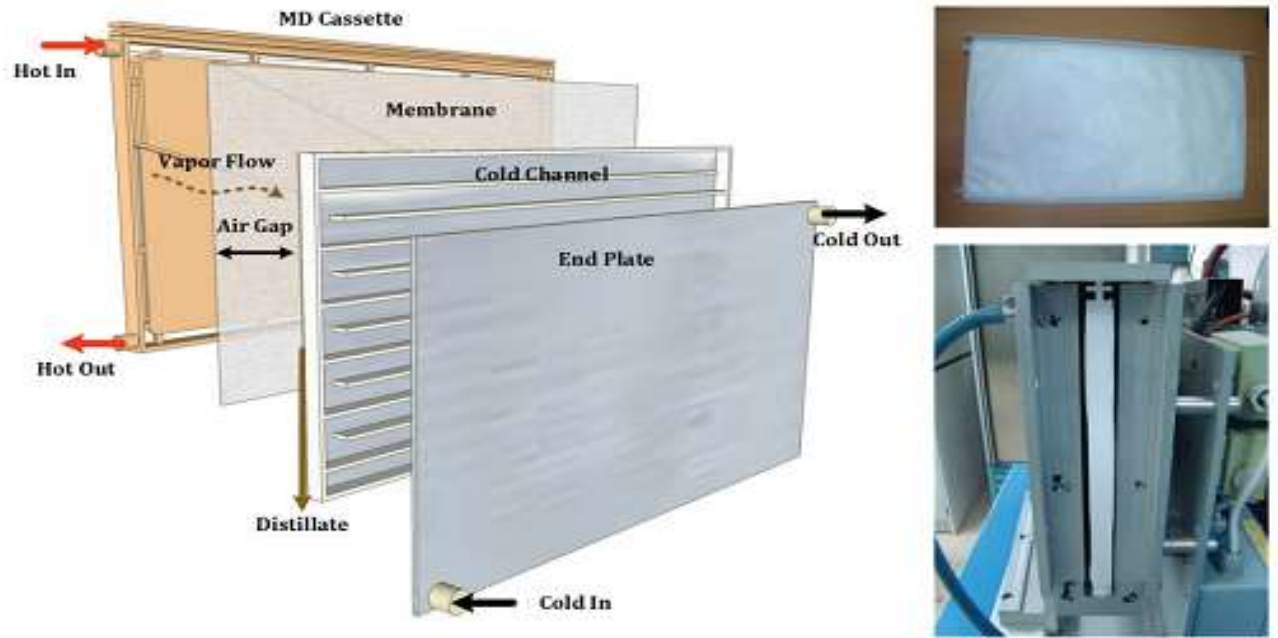

Figure 3. Bench-scale MD module and pictures of cassette fitted into module [30].

The most significant influential design variables on the AGMD performance are the feed inlet temperature $\left(\mathrm{T}_{\text {Hin }}\right)$, the cooling inlet temperature $\left(\mathrm{T}_{\mathrm{Cin}}\right)$ which is condensation temperature, the feed flow rate $\left(\mathrm{V}_{\mathrm{f}}\right)$ and feed concentration $\left(\mathrm{C}_{\mathrm{f}}\right)$. The selected performance indicators of the AGMD process are distillate flux $\left(J_{d}\right)$ and specific performance ratio (SPR), whereas $J_{d}$ is calculated by:

$$
J_{d}=\frac{M_{d}}{S . t}
$$

Where $M_{d}(\mathrm{~kg})$ is the mass of distillate water collected within the time $t$, and $S\left(\mathrm{~m}^{2}\right)$ is the effective membrane surface area of evaporation. SPR is obtained by:

$$
S P R=\frac{M_{d}}{Q_{m d}}
$$

$Q_{m d}(\mathrm{KWh})$ is the thermal energy supplied to the AGMD module.

The regression quadratic model with coded parameters can be expressed as:

$$
\begin{gathered}
Y=\beta_{0}+\beta_{1} X_{1}+\beta_{2} X_{2}+\beta_{3} X_{3}+\beta_{12} X_{1} X_{2}+\beta_{13} X_{1} X_{3}+ \\
\beta_{23} X_{2} X_{3}+\beta_{11} X_{1}^{2}+\beta_{22} X_{2}^{2}+\beta_{33} X_{3}^{2}
\end{gathered}
$$


Journal of Thermal Engineering, Research Article, Vol. 7, No. 2, Special Issue 13, pp. 117-133, February, 2021

Kumar et al. [30] determined the final regression equations for $J_{d}$ and $T_{\text {Hout }}$ in terms of actual operating parameters as follows:

$$
\begin{gathered}
J_{d}=-6.57+0.16 * T_{\text {Cin }}+0.15 * T_{\text {Hin }}-5.86 * 10^{-3} * V_{f}-5.77 * 10^{-3} * T_{\text {Cin }} T_{\text {Hin }}- \\
2.5 * 10^{-4} * T_{\text {Cin }} V_{f}+3.44 * 10^{-4} * T_{\text {Hin }} V_{f}+2.48 * 10^{-3} * T_{\text {Hin }}^{2} \\
T_{\text {Hout }}=3.097+6.82 * 10^{-2} * T_{\text {Cin }}+0.772 * T_{\text {Hin }}+3.5 * 10^{-3} * V_{f}+ \\
1.42 * 10^{-3} * T_{\text {Cin }} T_{\text {Hin }}
\end{gathered}
$$

Table 1. Operational conditions of tested AGMD module.

\begin{tabular}{|c|c|}
\hline Operational Parameter & Specification \\
\hline Feed flow rate, $\mathrm{L} / \mathrm{min}$ & 4,6 and 8 \\
Hot water operation temperature, ${ }^{\circ} \mathrm{C}$ & $40-80$ \\
Coldwater operation temperature, ${ }^{\circ} \mathrm{C}$ & $10-50$ \\
Tap water conductivity, $\mu \mathrm{S} / \mathrm{cm}$ & $500-10,000$ \\
\hline
\end{tabular}

The basic method of measuring collector performance is to expose the operating collector to solar radiation and measure the fluid inlet and outlet temperatures and the fluid flow rate. The useful gain is:

$$
\dot{\mathrm{Q}}_{\mathrm{u}}=m_{0} \mathrm{C}_{\mathrm{pf}}\left(\mathrm{T}_{0}-\mathrm{T}_{\mathrm{i}}\right)
$$

$m_{0}$ is the solar fluid mass flow rate $\left(\mathrm{kg} \cdot \mathrm{hr}^{-1}\right), C_{p f}$ is the specific heat capacity of solar fluid $\left(\mathrm{KJ} \cdot \mathrm{hr}^{-1}\right), \mathrm{T}_{0}$ and $\mathrm{T}_{\mathrm{i}}$ are the inlet and outlet temperature of the solar fluid (K).

Heat exchanger counter flow effectiveness is:

$$
\varepsilon=\frac{1-\exp \left(-\frac{U A}{C_{\min }}\left(1-\frac{C_{\min }}{C_{\max }}\right)\right)}{1-\left(\frac{C_{\min }}{C_{\max }}\right) \exp \left(-\frac{U A}{C_{\min }}\left(1-\frac{C_{\min }}{C_{\max }}\right)\right)}
$$

UA is the overall loss coefficient between the heater and its surroundings during operation $\left(\mathrm{kg} \cdot \mathrm{hr}^{-1}\right), C_{\text {max }}$ is the maximum capacity rate $\left(\mathrm{KJ} . \mathrm{hr}^{-1} \cdot \mathrm{K}^{)}, C_{\min }\right.$ is the minimum capacity rate $\left(\mathrm{KJ}^{\mathrm{h}} \cdot \mathrm{hr}^{-1} \cdot \mathrm{K}\right.$.

Required heating rate including efficiency effects in the auxiliary heaters is:

$$
\mathrm{Q}_{\mathrm{aux}}=Q_{\text {loss }}+Q_{\text {fluid }}
$$

With:

$$
Q_{\text {loss }}=U A\left(\bar{T}-T_{\text {env }}\right)+\left(1-\eta_{h t r}\right) \mathrm{Q}_{\max }
$$

And

$$
Q_{\text {fluid }}=\dot{\mathrm{m}}_{0} \mathrm{C}_{\mathrm{pf}}\left(\mathrm{T}_{\text {set }}-\mathrm{T}_{\mathrm{i}}\right)
$$


$\mathrm{Q}_{\mathrm{aux}}$ is the required heating rate including efficiency effects $\left(\mathrm{kg} \cdot \mathrm{hr}^{-1}\right), Q_{\text {fluid }}$ is the rate of heat addition to fluid stream $\left(\mathrm{kg} \cdot \mathrm{hr}^{-1}\right), Q_{\text {loss }}$ is the rate of thermal losses from the heater to environment $\left(\mathrm{kg} \cdot \mathrm{hr}^{-1}\right), \mathrm{Q}_{\max }$ is the maximum heating rate of the heater $\left(\mathrm{kg} . \mathrm{hr}^{-1}\right), \eta_{h t r}$ is an efficiency of the auxiliary heater, $m_{0}$ is the outlet fluid mass flow rate $\left(\mathrm{kg} . \mathrm{hr}^{-1}\right), C_{p f}$ is the fluid specific heat $\left(\mathrm{KJ} \cdot \mathrm{hr}^{-1}\right), \mathrm{T}_{\mathrm{i}}$ is the fluid inlet temperature $(\mathrm{K}),(\bar{T})$ brackish water average temperature $\mathrm{T}_{\text {set }}$ set temperature of heater internal thermostat $(\mathrm{K}), T_{\text {env }}$ is the temperature of heater surroundings for loss calculations $(\mathrm{K})$.

MD system determines the distillate production flow rate along with MD hot side outlet temperature. Other main components of the solar thermal MD system are the solar collectors, a heat exchanger, three pumps and a hot water storage tank. The heat exchanger transfers heat from the collectors to the MD feed water stored in a small tank from where the feed pumps to the MD module. Cold-water pumps to MD from a cold-water storage tank having temperatures according to the ambient conditions of the location. Table 2 shows the main specifications considered for the components of the solar thermal MD system. Five flat plate collectors having a total area of $12.75 \mathrm{~m}^{2}$ considered for both experiments and the simulation model. A simple storage tank with fixed inlets and uniform heat losses use for feeding water storage. The temperature differential controller uses to control the flow of heat transfer fluids in the solar thermal system. This model studies throughout the year, especially in December when the minimum radiation is incident on solar collectors in Ain-Temouchent.

Table 2. Main specifications for the solar thermal integrated MD system.

\begin{tabular}{|c|c|c|c|}
\hline Component & Parameter & Value & Unit \\
\hline Flat plate collectors & Collector absorber area & 12.75 & $\mathrm{~m}^{2}$ \\
& Collector efficiency & 0.781 & - \\
& Tilt angle & 35 & Degree \\
Heat exchanger & Effectiveness & 0.5 & - \\
MD hot water store & Volume & 100 & $\mathrm{~L}$ \\
MD hot pump & Flow rate & 420 & $\mathrm{~kg} . \mathrm{hr}^{-1}$ \\
Auxiliary heaters & Maximum heating rate & 1500 & $\mathrm{~W}$ \\
& Efficiency of the auxiliary heater & 1 & - \\
\hline
\end{tabular}

The use of solar energy considerably reduces the operating costs; however, its intermittent nature requires a non-stationary optimal operation that can be achieved through advanced control strategies. In this study, the control and model of the thermal system of the membrane make with the use of Photovoltaic panels for cost savings. Therefore, to reduce the operating cost, the photovoltaic system uses the storage battery that replaces the power load of the auxiliary heater, which appears in Figure 2. Then, the following output parameters, which are the outlet temperature of solar collector and auxiliary power supplied to the storage tank. The control and model of the thermal system of the distillation membrane also make with the use of Photovoltaic panels device for cost savings. In this study, a TRNSYS program [32] and PVGIS software [33] are used to predict the long-term performance of the solar water heating systems in different locations for distillation membrane, and they can simulate the system performances under different weather, among them the operating conditions in the weather of the state Ain-Temouchent, Algeria.

The PV system is calculated based on the parameters of Table 3 using PVGIS software and the following equations:

The peak power of the autonomous photovoltaic installation

$$
P_{c}=P_{p v}=\frac{D}{N * F}
$$

Pc Power of the PV field, $D$ Daily need $\mathrm{kWh} /$ jour, $F$ Form factor, $N$ number of hours equivalent. 
Journal of Thermal Engineering, Research Article, Vol. 7, No. 2, Special Issue 13, pp. 117-133, February, 2021

$$
N=\frac{G_{T}(t)}{G_{T, S T C}}
$$

$G_{T}(t)$ is the solar radiation incident on the solar -PV array in the current time step $\mathrm{kW} / \mathrm{m}^{2}$.

$G_{T, S T C}$ is the incident radiation at standard test conditions $\mathrm{kW} / \mathrm{m}^{2}$.

The size of the inverter from 25 to $30 \%$ must be greater than the total quantity of devices. In the case of a device or compressor, the size of the inverter must be at least 3 times the capacity of these devices and must be added to the capacity of the inverter to handle the surge current during startup.

The storage capacity of the battery is calculated according to the following relation [34], [35]:

$$
C(W h)=\frac{D * 1000 * N_{j}}{n_{b} * P_{d} * P_{r}}
$$

$D$ Daily need, $N_{j}$ Autonomy number of days without radiation, $U_{b}$ Nominal voltage of the batteries, $n_{b}$ Battery efficiency, $P_{r}=(1-$ online losses $), P_{d}$ Depth of the discharge.

Table 3. Technical characteristics of PV panels.

\begin{tabular}{|l|c|c|c|}
\hline Component & Parameter & Value & Unit \\
\hline PV panel & Module area & 1.6 & $\mathrm{~m}^{2}$ \\
& Power tolerance & \pm 5 & $\%$ \\
& Solar Cells & 36 & cell \\
& Module open-circuit voltage at reference conditions & 38.9 & $\mathrm{~V}$ \\
Battery & Module short-circuit voltage at reference conditions & 9.31 & Ampere \\
& Tolerance for iterative calculations & 16.7 & Ah \\
Inverter & Charging efficiency & 0.8 & - \\
& High limit on the fractional state of charge (FSOC) & 1 & - \\
\end{tabular}

\section{Trnsys Model}

The model of solar thermal membrane distillation system with AGMD and the photovoltaic system is developed using TRNSYS software, which is a quasi-steady-state simulation program. TRNSYS enables system components represented as preformats to be selected and interconnected in any desired manner to construct a system's model. To facilitate the selection of the system components, it is important to develop an information flow diagram. The information flow diagram for the models is shown in Fig 2. The main component of the model is the AGMD unit, which is represented by a new equation in TRNSYS. Additional components to the model include TYPE109-TM2 reading and processing of meteorological data, Type 91 heat exchanger, Type 39 storage tank, Type 1 flat plate collector, Type 2 differential temperature controller, Type 3 single speed pump, Type 6 auxiliary heaters, Type 94 photovoltaic panels, Type 47 storage battery, Type 48 inverter, Type 14 forcing functions, Type 57 unit conversion and Type 65 online plotter. Tables 1 and 2 show the values of parameters used in the TRNSYS model.

To obtain good harmonic results, we have chosen the time from 8 am to $6 \mathrm{pm}$ to operate the AGMD system. In this time, the solar radiation required by both solar and photovoltaic panels is present in the winter season with various changing climatic conditions in Ain-Temouchent, Algeria. 


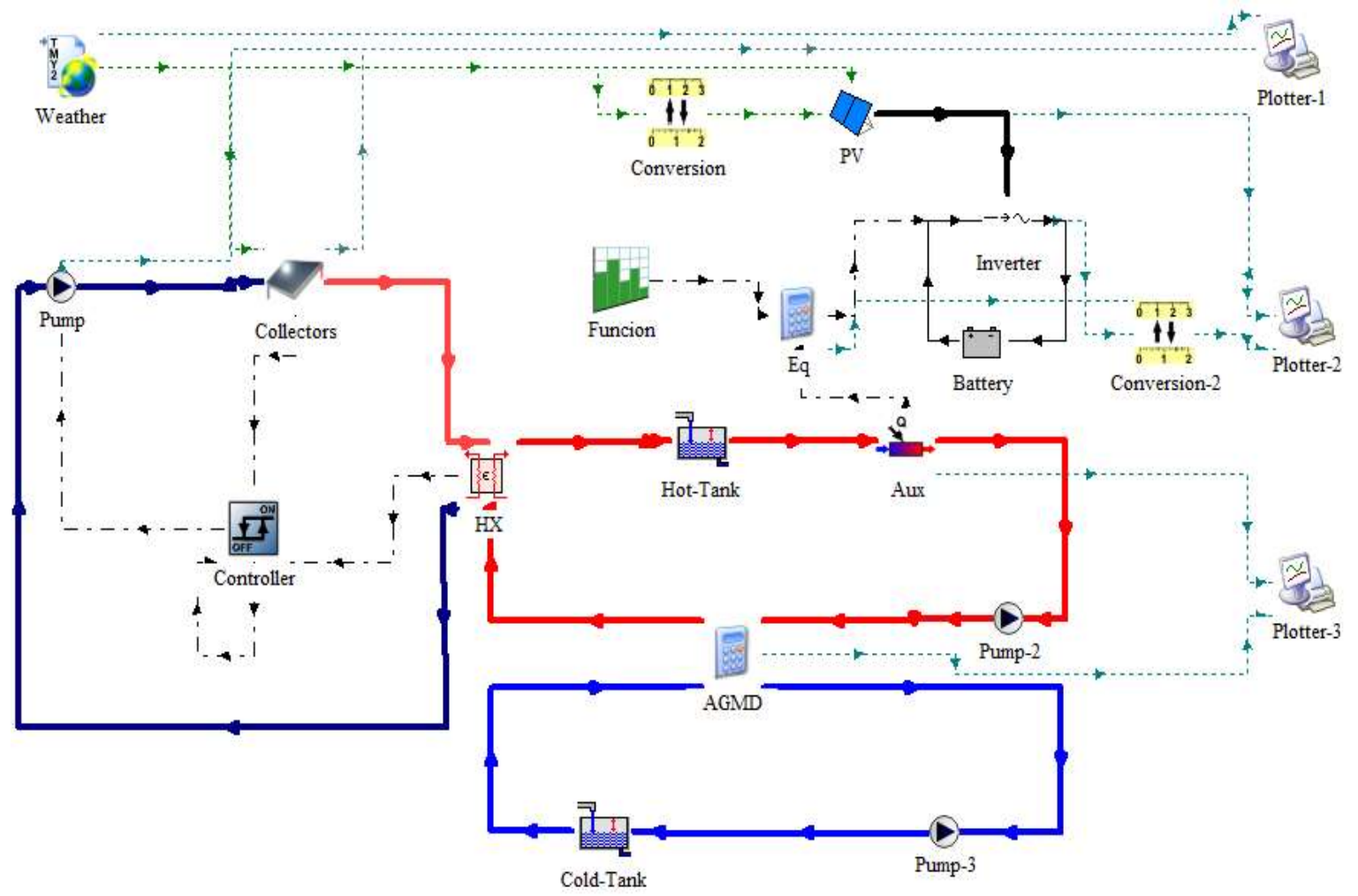

Figure 4. Assembly diagram of the AGMD system in the TRNSYS simulation.

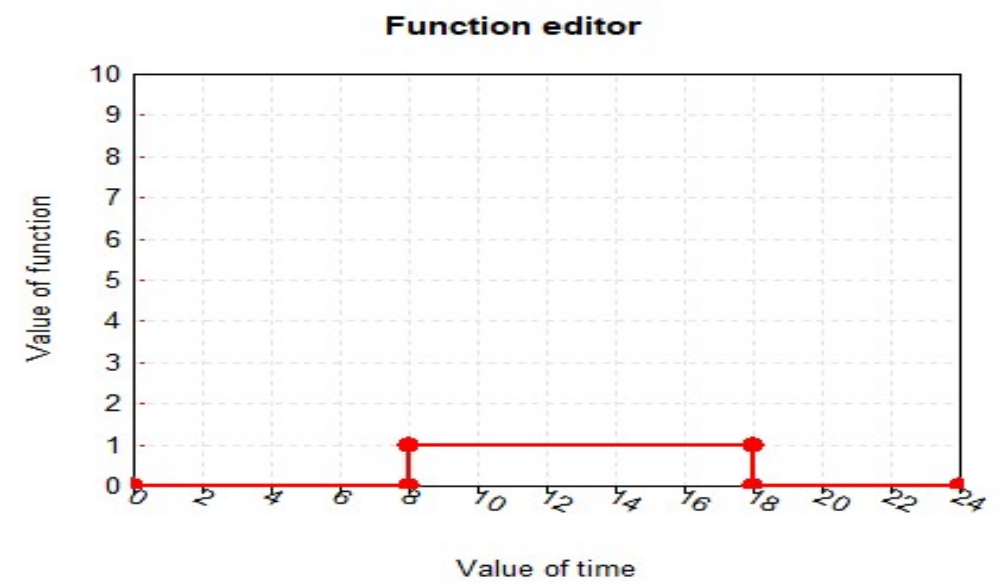

Figure 5. The time value for operation of the AGMD system with ON / OFF control.

\section{RESULTS AND DISCUSSION \\ Weather data}

This model has been studied in Ain-Temouchent weather, fig 6 shows changing climate conditions throughout the year. The weather in the Ain-Temouchent state is pleasant, warm and moderate in general. At an average temperature of 25.7 degrees Celsius, August is the hottest month of the year. At $10.8^{\circ} \mathrm{C}$ on average, January is the coldest month of the year. Therefore, in fig $6 \mathrm{a}$, we notice a change in temperature throughout the year, which reaches up to 40 degrees Celsius in August, and we note that the wind is moderate and does not exceed the velocity of $15 \mathrm{~m} / \mathrm{s}$. 
For the irradiation, it changes during the months of the year and reaches up to $220 \mathrm{KWh} / \mathrm{m}^{2}$ in August and July as shown in fig $6 \mathrm{~b}$, because the temperature is high in this period of the year. This study has been simulating for a full year and the results will appear on different days $(11 / 12,11 / 03,11 / 08$, and 11/10).

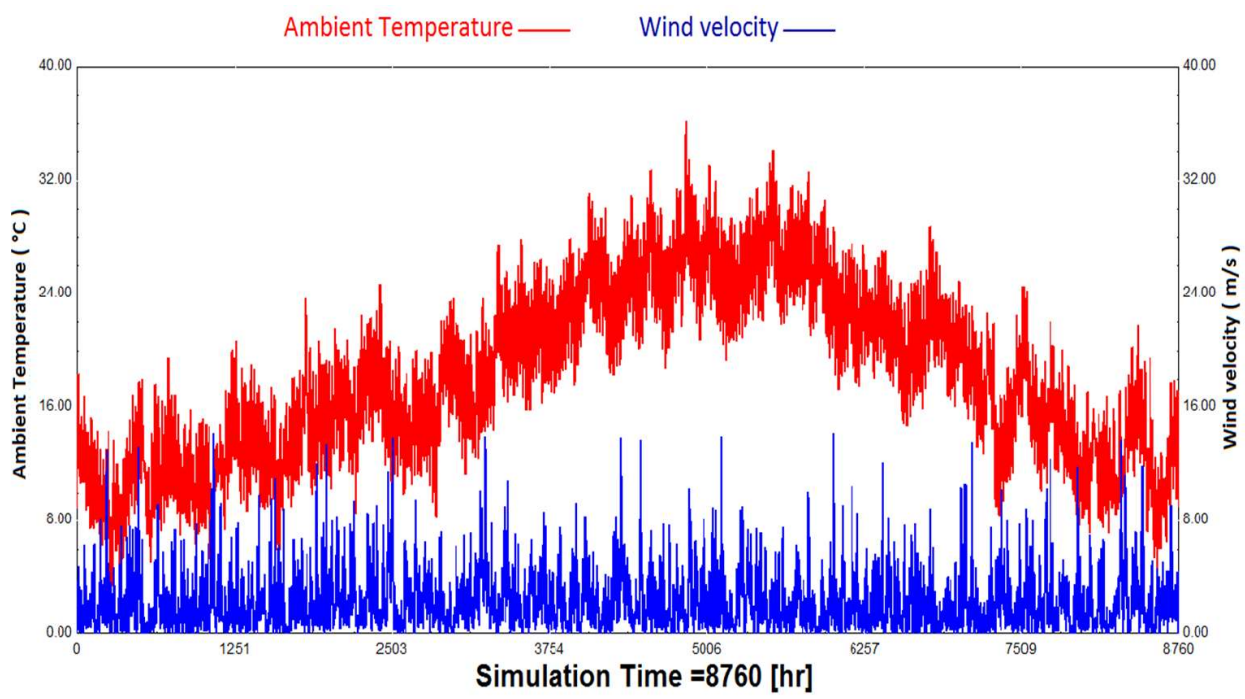

(a)

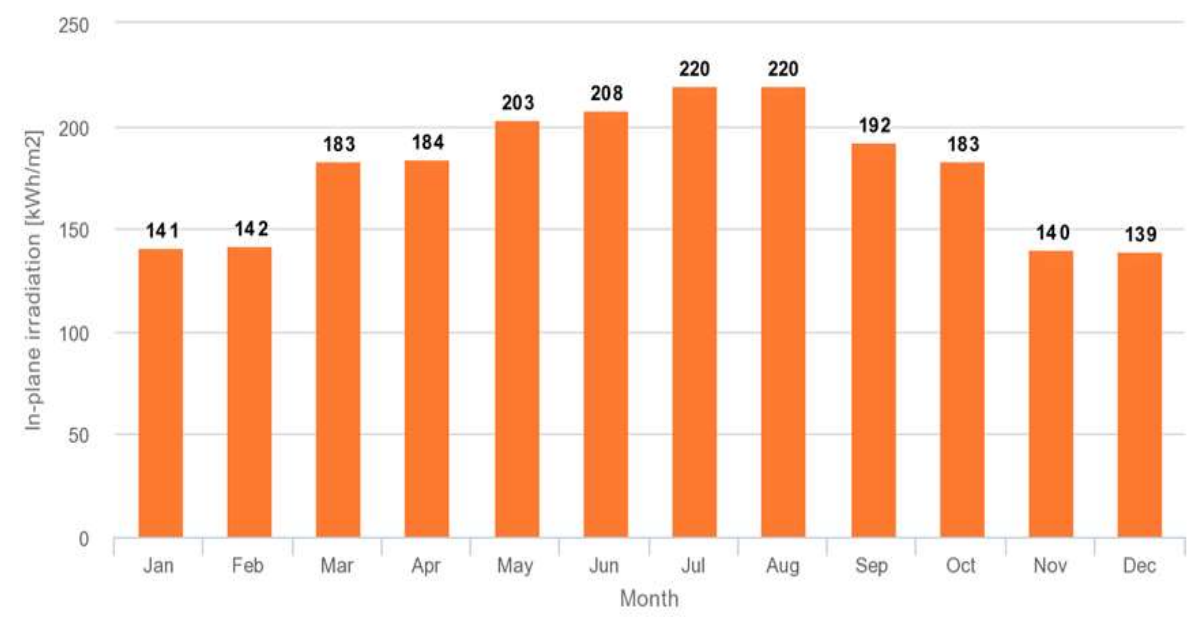

(b)

Figure 6. (a) Ambient temperature, wind velocity and (b) irradiation in the weather of Ain-Temouchent.

\section{Model validation}

Based on the experimental characteristics of AGMD module, the simulation results have been validated with experimental data obtained from a pilot-scale solar thermal membrane distillation system that installed in UAE [30]. This part aimed at checking the validity of the input data and output results to obtain correct and reliable results in the same conditions used in the maximum radiation from October on solar collectors in UAE.

In fig 7, a single cassette air-gap membrane distillation (AGMD) module is characterized to identify the effect of process parameters on distillate flux. Figure 7 shows a comparison between the results of this simulation and the applied results from Kumar's article et al. [30]. The results showed excellent compatibility between them, and this is shown by the distillation flow rate value. Therefore, favorable conditions were determined and validated to obtain a distillate flow rate of $4.5 \mathrm{~kg} / \mathrm{h}$. 


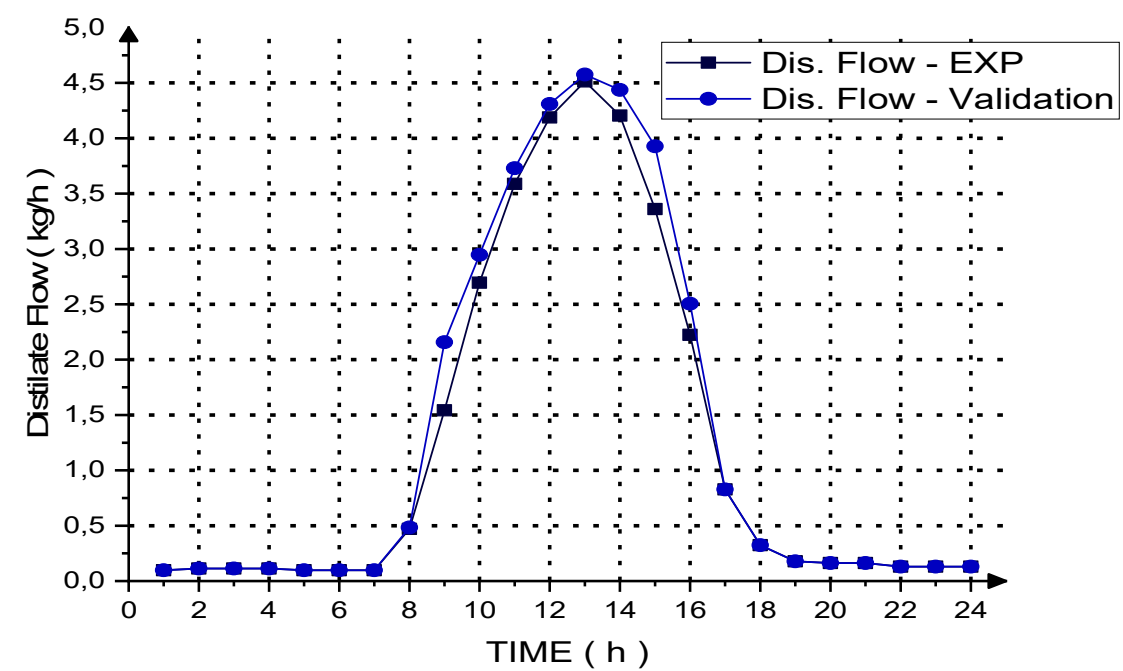

Figure 7. Comparison of distillate flow between the simulation and the experimental data [30].

Fig 8 shows the comparison of the inlet hot feed side temperature of the AGMD module between the given experiment results [30] and the simulated results obtained from the model used. It can be noticed that the inlet hot feed side temperature of the AGMD module predicted by the present model has a good agreement with the experiment. The outlet temperature of the thermal system of an AGMD module reaches $84^{\circ} \mathrm{C}$ in the maximum radiation from October on solar collectors in UAE. Based on this result as shown in figure 8 , the present study aims at simulating the solarbased solar thermal membrane distillation system considered as a field trial installation in UAE.

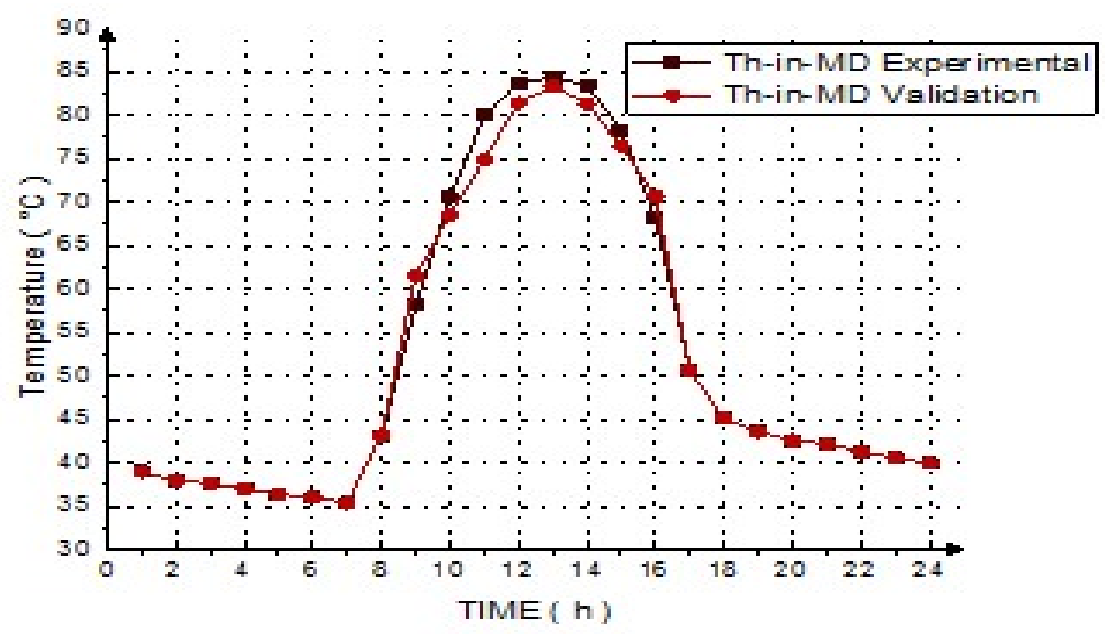

Figure 8. Comparison of temperature outlet of the thermal system between the simulation and the experimental data [30].

\section{Temperatures inlet of AGMD and Distillate Flows without auxiliary heaters}

The change in feed inlet temperature of AGMD module profiles without using an auxiliary heater for day $11^{\text {th }}$ of December, March, August, and October is illustrated in Fig 9. The results show that the temperature decreases in December that reach $52{ }^{\circ} \mathrm{C}$, but it increases in August when the temperature is high and reaches $87{ }^{\circ} \mathrm{C}$, as it reaches 72 and $81{ }^{\circ} \mathrm{C}$ respectively in March and October. This change is due to the change in ambient temperature and radiation in the daytime and, their difference from month to month. 


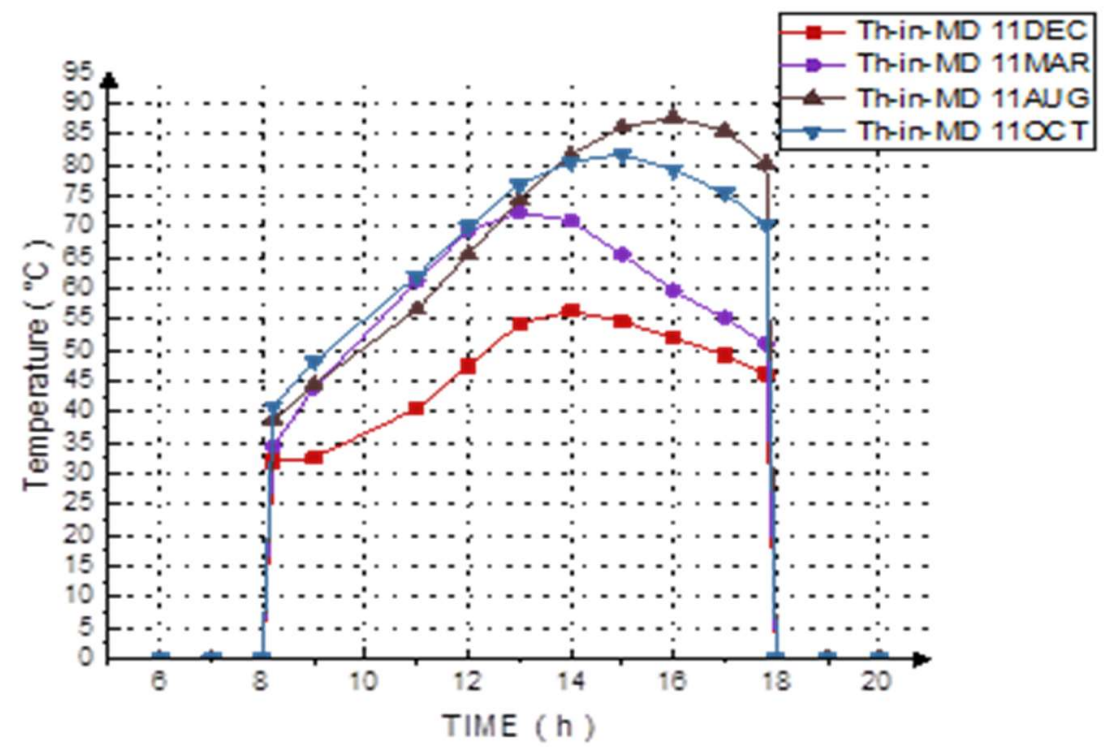

Figure 9. Feed AGMD inlet temperatures without auxiliary heaters $\left({ }^{\circ} \mathrm{C}\right)$.

Fig 10. illustrates the amount of distilled water obtained from AGMD in different climatic conditions throughout the year. We note that the productivity of distilled water is decreased in December and reaches $1.6 \mathrm{~kg} / \mathrm{hr}$ and increases in August, which reaches $5.5 \mathrm{~kg}$ /hour, where it is 3.4 and 4.6 in March and October respectively. Consequently, the changes in temperature and climatic conditions as clarified in Fig 6 effect the distilled water flow in different months on the same day $11^{\text {th }}$ of four months selected. The temperature is related to the flow of distilled water. Therefore, when the temperature decreases, the flow of distilled water also decreases and vice versa.

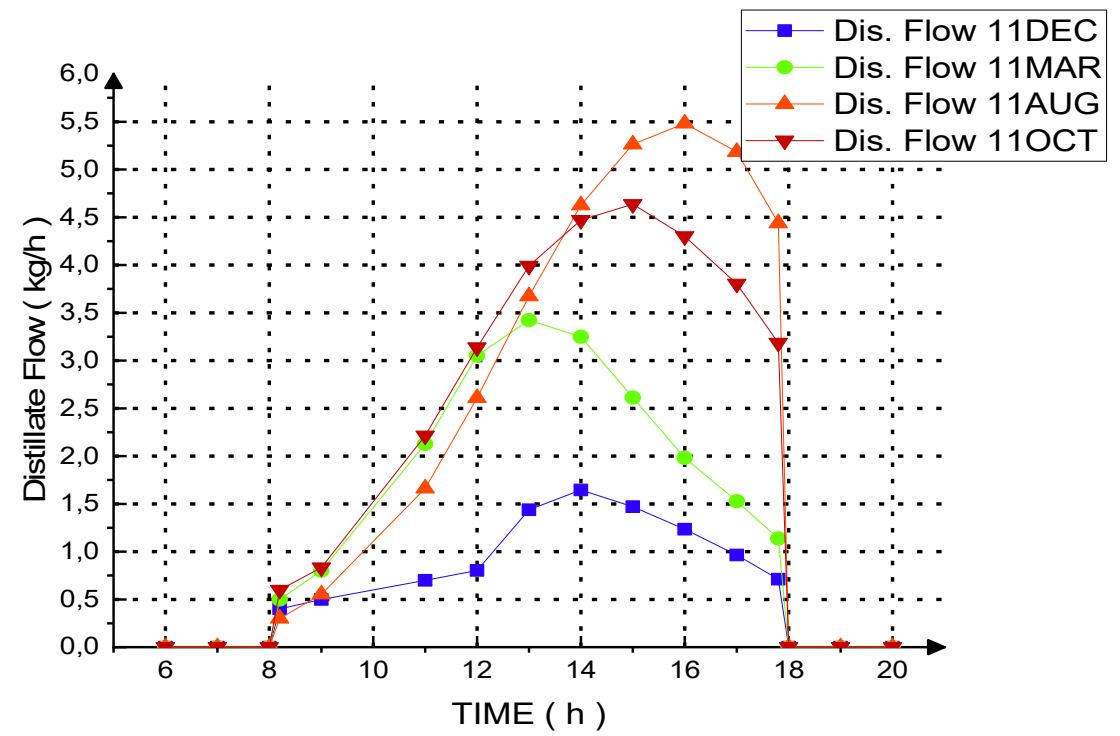

Figure 10. Distillate flows of AGMD module without auxiliary heaters $(\mathrm{Kg} / \mathrm{h})$.

\section{Temperatures inlet of AGMD and Distillate Flows with auxiliary heaters}

In Fig 11, there are feed inlet temperatures changes of the AGMD module in different climatic conditions by adding an electrical heater to this used system. Therefore, we notice that inlet temperatures of AGMD reach 85-87 $\mathrm{C}^{\circ}$ and stay stable in each day: $(11 / 12,11 / 03,11 / 08$, and 11/10) and in different climatic conditions throughout the year 
in Ain-Temouchent as well. The auxiliary heater compensates for the necessary heat for the AGMD unit. Thus, this system is appropriate to keep the temperatures stable at the same temperature 87 degrees Celsius for different seasonal weather conditions in Ain-Temouchent.

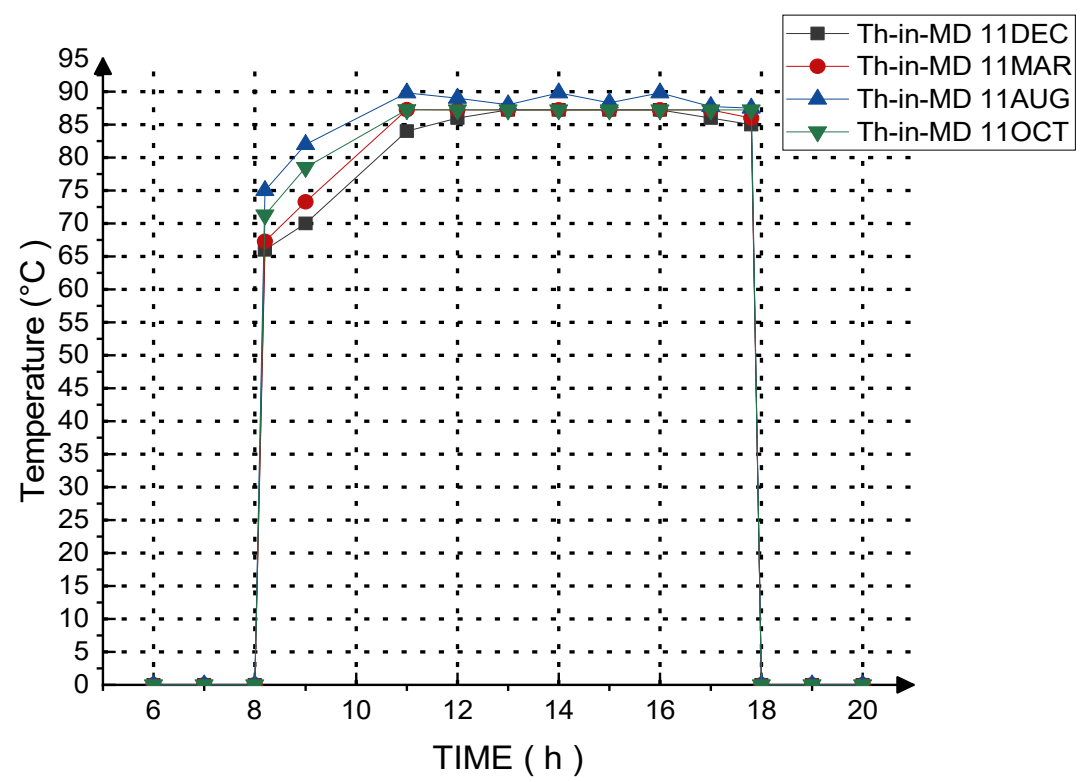

Figure 11. Feed AGMD inlet temperatures with auxiliary heaters $\left({ }^{\circ} \mathrm{C}\right)$.

Fig 12 illustrates the variations of the distilled water flow produced by the AGMD module by adding an auxiliary heater at different climatic conditions for four months. In this case, we note that distilled water flow from the distillation membrane reaches $5.5 \mathrm{~kg} / \mathrm{h}$ and stays stable on different days throughout the year. This also explains why the stability of heat occurs when adding an auxiliary heater to this system and this greatly helps in the flow of distilled water that reaches the same flow $5.5 \mathrm{~kg}$ /hour in different climatic conditions throughout the year in the weather of Ain-Temouchent.

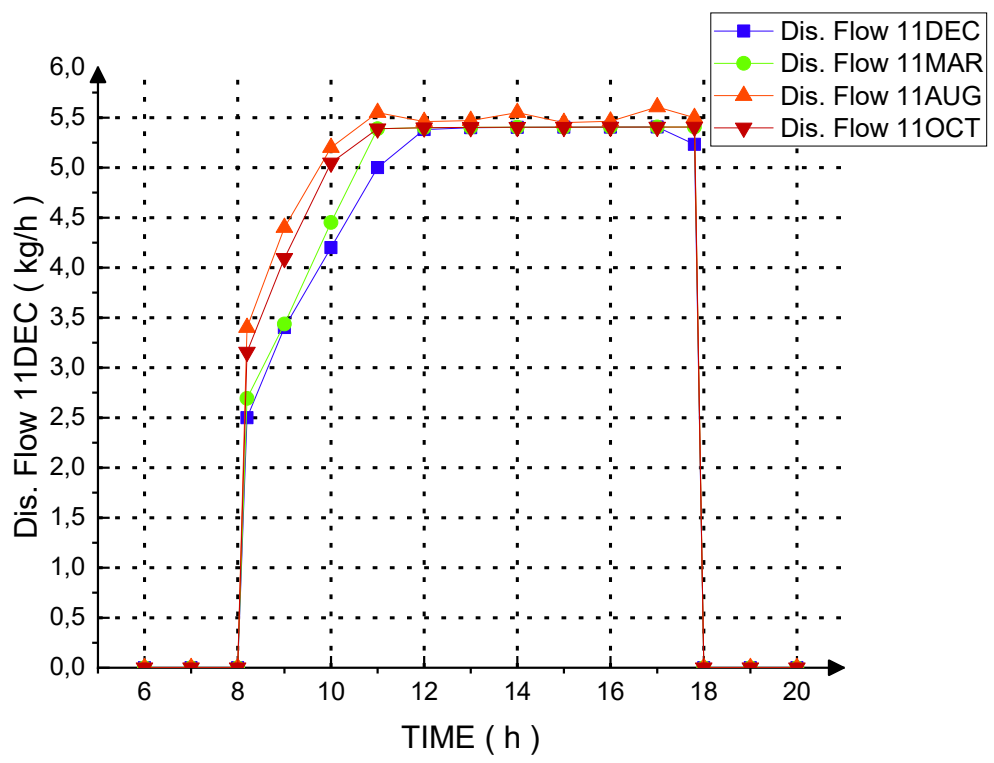

Figure 12. Distillate flows of AGMD module with auxiliary heaters $(\mathrm{Kg} / \mathrm{h})$. 


\section{Auxiliary heating rate and power to load of the photovoltaic (PV) system}

Adding an auxiliary heater consumes additional electrical energy to this system and that is due to interruptions and climate changes in Ain-Temouchent throughout the year (as shown in Fig 13). We note on December 11, the electricity power of the auxiliary heater reaches $1.5 \mathrm{~kW}$, unlike on August 11, when the required energy reaches only $0.28 \mathrm{~kW}$ because the temperature in this month increases (as shown in figure 4). In addition to that, the electric power in March and October reaches between 0.1-1.4 and 0.4-1.4 KW respectively. Thus, when the more temperature decreases, the more electric power is required to reach the desired value. However, the auxiliary heater is useful to producing more distilled water with a stable flow throughout the year in the weather of Ain-Temouchent, but it consumes additional electrical energy that affects and increases the cost of this water desalination system.

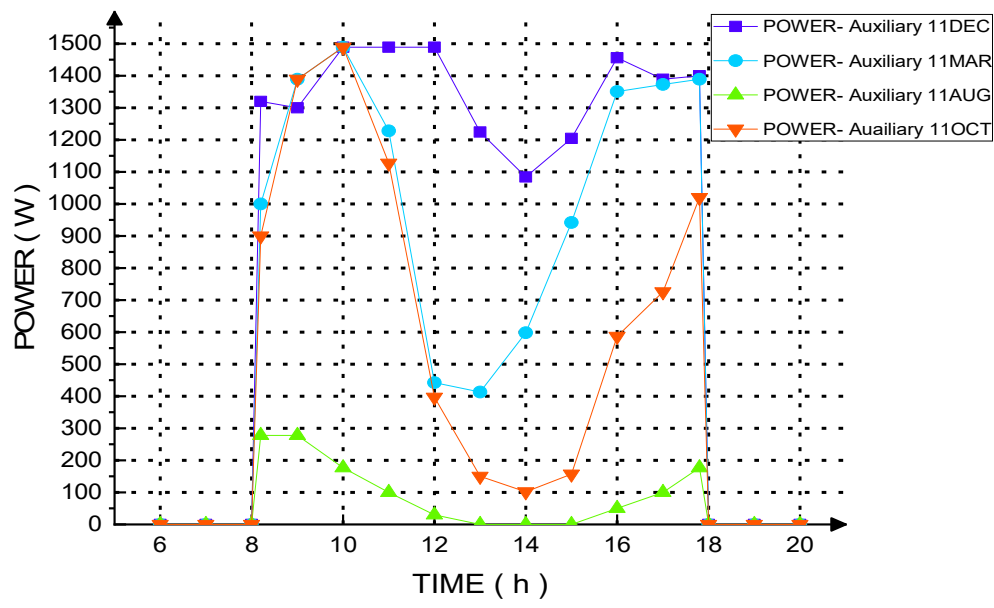

Figure 13. Power to load of the auxiliary heaters of the thermal system for AGMD.

To save costs, a photovoltaic system uses based on renewable energy (solar energy). Therefore, the energy needed calculates for the auxiliary heater and replaces by 10 photovoltaic panels, each one has an area of $1.6 \mathrm{~m}^{2} \mathrm{using}$ seven of the energy storage batteries $(12 \mathrm{~V}, 200 \mathrm{Ah})$ with 1.5 kilowatts via TRNSYS and PVGIS help programs. Accordingly, the purpose of this study is the use of solar panels in the photovoltaic system to produce the necessary electrical energy. Therefore, we note in Fig 14 that the electric power of the auxiliary heater is the same energy that comes out of the photovoltaic system. Consequently, the electrical energy of the auxiliary heater replaces by using the PV system panels in various intermittent climatic conditions $(11 / 12,11 / 03,11 / 08$, and11/10) as shown in figure 14.

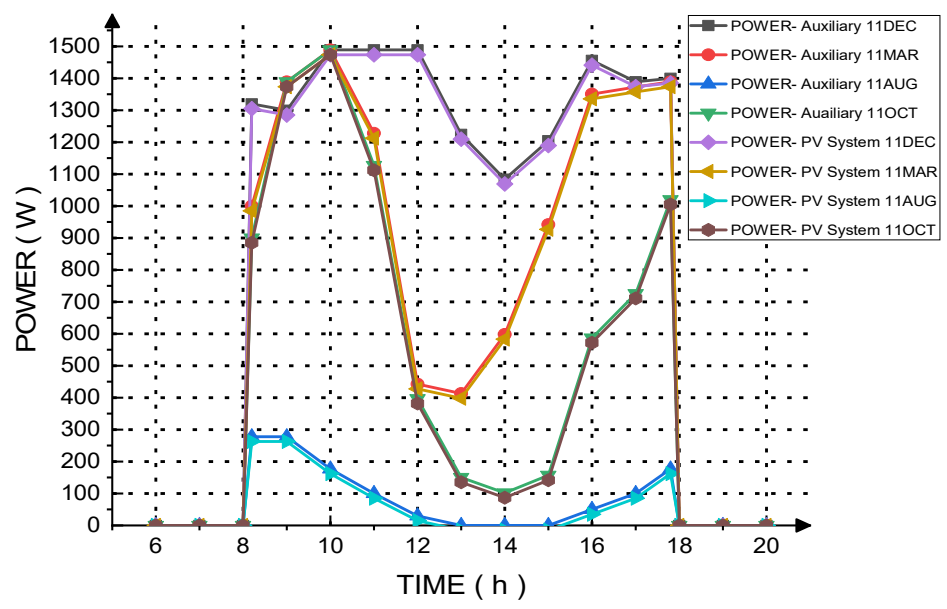

Figure 14. Power to load of the photovoltaic system for the auxiliary heaters for AGMD. 


\section{CONCLUSION}

In this paper, a dynamic simulation of the membrane distillation module integrated solar thermal system has been reported along with validation of the system model by comparing it with the experimental data obtained from a pilot-scale setup located in UAE. The results obtained showed that the validated a TRNSYS model could be used to predict long-term performance and to study the performances of the AGMD systems in different weather and operating conditions for the Ain-Temouchent city, Algeria.

A TRNSYS model develops solar water heating systems with flat plate collectors with an area of $12.75 \mathrm{~m}^{2}$, heat exchanger, storage tanks, the auxiliary heater, and 10 photovoltaic panels; each one has an area of $1.6 \mathrm{~m}^{2}$ with seven of the energy storage batteries $(12 \mathrm{~V}, 200 \mathrm{Ah})$. The model has been validated using the system data installed in the UAE, where the following output parameters have been carefully considered, namely the temperature of the thermal system outlet and the additional energy provided to the hot storage tank. Accordingly, the control system and model of the thermal system of AGMD process designs to produce distillate water depending on the solar energy only as permanent and renewable energy to save all costs, whereas the auxiliary heating consumed the highest value of 1.5 $\mathrm{KW}$ to augment the water temperature to $87^{\circ} \mathrm{C}$ in the cold climatic conditions. Besides, the electric energy of the pumps uses to perform the AGMD process is 0.6 kilowatts, which is calculated and added to the photovoltaic system using TRNSYS and PVGIS programs.

Therefore, the thermal system temperatures reach the same value of $87^{\circ} \mathrm{C}$ on different days from the year $(11 / 12,11 / 03,11 / 08$, and 11/10). Thus, The proposed solar AGMD system has shown favorable potential application in desalination of water can produce $5.5 \mathrm{~kg} / \mathrm{h}$ of distilled water at different times and in changing climatic conditions throughout the year in Ain-Temouchent weather, Algeria.

Thus, this is equivalent to a daily distillate production rate and can make this contemporary model for the AGMD process usable and suitable to be a system compatible in the future with all intermittent climatic conditions and all over the world.

\section{Acknowledgments}

The authors acknowledge financial supports of the FNRSDT/DGRSDT within the framework of ERANETMED3 (Project.ERANETMED3-166 EXTRASEA) from the directorate general for scientific research and technological development.

\section{NOMENCLATURE}

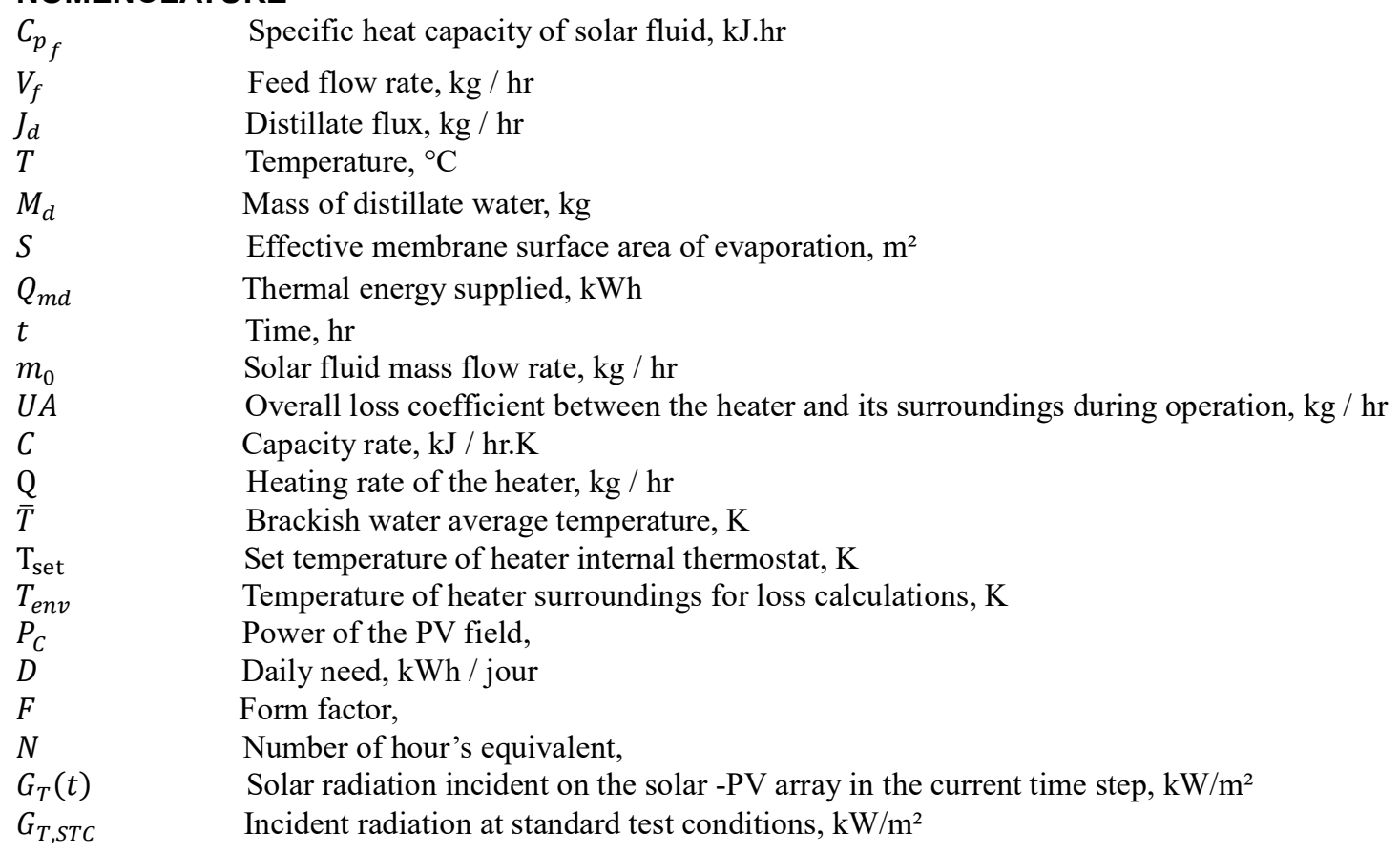


Journal of Thermal Engineering, Research Article, Vol. 7, No. 2, Special Issue 13, pp. 117-133, February, 2021

$N_{j} \quad$ Autonomy number of days without radiation,

$U_{b} \quad$ Nominal voltage of the batteries,

$P \quad$ Discharge.

Greek symbols

$\eta$

Heat exchanger counter flow effectiveness

Efficiency

Subscripts

in Inlet

out Outlet

h Hot

c Cold

$p \quad$ Permeate

d Depth

$h r \quad$ Hour

aux Auxiliary

loss Losses

htr Heater

$\max \quad$ Maximum

$\min \quad$ Minimum

Abbreviations

MD Membrane Distillation

AGMD Air-Gap Membrane Distillation

DCMD Direct Contact Membrane Distillation

DMV Vacuum Membrane Distillation

SGMD Sweeping Gas Membrane Distillation

FPC Flat Plate Collector

SDHW Solar Domestic Hot Water

PV Photovoltaic

PTFE Polytetrafluoroethylene

PVDF Polyvinylidene fluoride

PE Polyethylene

PP Polypropylene

\section{REFERENCES}

[1] Alkhudhiri A, Darwish N, Hilal N. Membrane distillation: A comprehensive review. Journal of Desalination 2012;287:2-18. doi: 10.1016/j.desal.2011.08.027

[2] Amir G, Nasim H, Alireza N, Parisa H. Exergy Based Optimization of a Biomass and Solar Fuelled CCHP Hybrid Seawater Desalination Plant. Journal of Thermal Engineering 2017;3:1034-1043. doi: 10.18186/thermal.290251

[3] Hadi G, Ghader A. Performance Analysis and Thermodynamic Modeling of a Poly Generation System by Integrating a Multi-Effect-Desalination Thermo-Vapor Compression (MED-TVC) System with a Combined Cooling, Heating and Power (CCHP) System. Journal of Thermal Engineering 2018;4:1963-1983. https://doi.org/10.18186/journal-of-thermal-engineering.410264

[4] Omid M, Ali K, Chaiwat J, Phubate T, Somchai W, Raviwat S. Solar Distillation Practice For Water Desalination Systems. Journal of Thermal Engineering 2015;1:287-288. doi: 10.18186/jte.93924

[5] Phattaranawik J, Jiraratananon R, Fane A. Heat transport and membrane distillation coefficients in direct contact membrane distillation. Journal of Membrane Science 2003;212:177-193. doi: 10.1016/S03767388(02)00498-2

[6] Teoh M, Chung T. Membrane distillation with hydrophobic macrovoid-free PVDF-PTFE hollow fiber membranes. Separation and Purification Technology 2009;66:229-236. doi:10.1016/j.seppur.2009.01.005

[7] Verma SK, Singhal P, Chauhan DS. A synergistic evaluation on application of solar-thermal energy in water 
Journal of Thermal Engineering, Research Article, Vol. 7, No. 2, Special Issue 13, pp. 117-133, February, 2021

purification: Current scenario and future prospects. Journal of Energy Conversion and Management 2019;180:372-390. doi:10.1016/j.enconman.2018.10.090

[8] Mohamed K, Takeshi M. Book of Membrane Distillation 2011;1:1-16. doi:10.1016/b978-0-444 53126$1.10001-6$

[9] Ruh U, Majeda K, Richard JE, James TM, Mohammad A, Mohamed G, Vahedi TH. Energy efficiency of direct contact membrane distillation. Journal of Desalination 2018;433:56-67. doi: 10.1016/j.desal.2018.01.025

[10] Qtaishata M, Matsuura T, Kruczek B, Khayet M. Heat and mass transfer analysis in direct contact membrane distillation. Journal of Desalination 2008;219:272-292 doi:10.1016/j.desal.2007.05.019

[11] Hassler G L. U.S. patent US3129146A (14 April 1964).

[12] Weyl P K. U.S. patent US3340186A (5 September 1967).

[13] Jonsson AS, Wimmerstedt R, Harrysson AC. Membrane Distillation-A Theoretical Study of Evaporation Through Microporous Membranes. Journal of Desalination 1985;56:237. doi:10.1016/0011-9164(85)85028-1

[14] Gostoli C, Sarti GC, Matulli S. Low Temperature Distillation Through Hydrophobic Membranes. Journal of Separation and Purification Technology 1987;22: 855. doi:10.1080/01496398708068986

[15] Banat FA, Al-Rub FA, Jumah R, Shannag M. Theoretical investigation of membrane distillation role in breaking the formic acid-water azeotropic point: Comparison between Fickian and Stefan-Maxwell-based models. International Communications in Heat and Mass Transfer 1999;26:879-888. doi:10.1016/s07351933(99)00076-7

[16] Hanemaaijer JH, Van MJ, Jansen AE, Dotremont C, Sonsbeek E, Yuan T, De RL. Memstill membrane distillation - a future desalination technology. Journal of Desalination 2006;199:175-176. doi:10.1016/j.desal.2006.03.163

[17] Vandita TS, Thombre S. Air gap membrane distillation: A review. Journal of Renewable and Sustainable Energy 2019;11:45-90. doi: 10.1063/1.5063766

[18] Duong HC, Cooper P, Nelemans B, Cath TY, Nghiem LD. Evaluating energy consumption of air gap membrane distillation for seawater desalination at pilot scale level. Journal of Separation and Purification Technology 2016;166:55. doi:10.1016/j.seppur.2016.04.014

[19] Minier-Matar J, Hussain A, Janson A, Benyahia F, Adham S. Field evaluation of membrane distillation technologies for desalination of highly saline brines. Journal of Desalination 2014;351:101-108. doi:10.1016/j.desal.2014.07.027

[20] Schwantes R, Cipollina A, Gross F, Koschikowski J, Pfeifle D, Rolletschek M, Subiela V. Membrane distillation: Solar and waste heat driven demonstration plants for desalination. Journal of Desalination 2013;323:93-106. doi:10.1016/j.desal.2013.04.011

[21] Alsaadi AS, Ghaffour N, Li JD, Gray S, Francis L, Maab H, Amy GL. Modeling of air-gap membrane distillation process: A theoretical and experimental study. Journal of Membrane Science 2013;445:53-65. doi:10.1016/j.memsci.2013.05.049

[22] Swaminathana J, Chunga HW, Warsingera DM, AlMarzooqib FA, Arafatb HA. Energy efficiency of permeate gap and novel conductive gap membrane distillation. Journal of Membrane Science 2016;502:171-178. doi:10.1016/j.memsci.2015.12.017

[23] Alklaibi AM, Lior N. Membrane-distillation desalination: Status and potential. Journal of Desalination 2005;171:111-131. doi:10.1016/j.desal.2004.03.024

[24] Camacho L, Dumée L, Zhang J, Li J-d, Duke M, Gomez J, Gray S. Advances in Membrane Distillation for Water Desalination and Purification Applications. Journal of Water 2013;5(1):94-196. doi:10.3390/w5010094

[25] Chafidz A, Esa DK, Irfan W, Yasir K, Abdelhamid A, Saeed MA. Design and fabrication of a portable and hybrid solar-powered membrane distillation system. Journal of Cleaner Production 2016;133:631-647. doi:10.1016/j.jclepro.2016.05.127

[26] Kullab A, Chuanfeng L, Andrew R. Martin. Solar desalination using membrane distillation: Technical evaluation case study, In Solar World Congress 2005: Bringing Water to the World, Including 34th ASES Annual Conference and 30th National Passive Solar Conference; Orlando, FL, United States 2005; 2732 2737.

[27] Banat B, Fawzi A, Jana S. Theoretical and experimental study in membrane distillation. J of Desalination 1994;95(1):39-52. doi:10.1016/0011-9164(94)00005-0

[28] Khan EU, Martin AR. Water purification of arsenic-contaminated drinking water via air gap membrane distillation (AGMD). Journal of Periodica Polytechnica Mechanical Engineering 2014;58(1):47-53. doi:10.3311/ppme.7422

[29] He Q, Li P, Geng H, Zhang C, Wang J, Chang H. Modeling and optimization of air gap membrane distillation system for desalination. Journal of Desalination 2014;354:68-75. doi:10.1016/j.desal.2014.09.022 
Journal of Thermal Engineering, Research Article, Vol. 7, No. 2, Special Issue 13, pp. 117-133, February, 2021

[30] Uday KN, Martin A. Experimental modeling of an air-gap membrane distillation module and simulation of a solar thermal integrated system for water purification. Journal of Desalination and Water Treatment 2017;84:123-134. DOI:10.5004/dwt.2017.21201

[31] Asim M, Uday KN, Martin A. Feasibility analysis of solar combi-system for simultaneous production of pure drinking water via membrane distillation and domestic hot water for single-family villa: pilot plant setup in Dubai. Journal of Desalination and Water Treatment 2015;57(46):21674-21684. doi:10.1080/19443994.2015.1125806

[32] TRNSYS, Transient System Simulation, Univ. of Wisconsin Madison, WI: Solar Energy Laboratory,2017;2:1129.

[33] PVGIS, Photovoltaic Geographical Information System, JRC European Commission, Joint Research Center 2007.

[34] Mahmoud MM, Ibrik IH. Techno-economic feasibility of energy supply of remote villages in palestine by PVsystems, diesel generators and electric grid. Journal of Renewable and Sustainable Energy Reviews 2006;10:128-138. doi:10.1016/j.rser.2004.09.001

[35] Stuart RW, Martin AG, Muriel EW, Richard C. Applied photovoltaics second edition first published by earth scan in the UK and USA in 2007 copyright (C) 2007; arc, ISBN-10:1-84407-401-3 